\title{
STAKEHOLDERS' PERCEPTION IN THE LAGUNA STATE POLYTECHNIC UNIVERSITY'S IMPLEMENTATION OF DISCIPLINE, SAFETY AND SECURITY MEASURES
}

\author{
Maryjane D. Fuentes, DPA \& Arbyn Luistro Almonte, MPA
}

Article DOI: https://doi.org/10.36713/epra6580

\begin{abstract}
The main objective of this study was to determine the stakeholders (faculty/personnel, students, and clients) perception in the implementation of LSPUs Discipline, Safety and Security Measures. The research method used for this study is descriptive research to gather information regarding the problem. It is specifically designed for the collection of data in order to test the hypotheses and answer the questions concerning the study. The respondents of this study were fifty (50) employees, fifty (50) students, and fifty (50) clients in each of the four campuses of the Laguna State Polytechnic University comprised of six hundred (600) total respondents from Siniloan, Santa Cruz, San Pablo City and Los Baños, campuses. The following statistical tools were used; weighted mean and standard deviation and Pearson Product Moment Correlation. The Pearson's $R$ was used to test the individual relationship between the Faculty/Personnel, Students, and Clients/Visitors perception on the implementation of Laguna State Polytechnic University's Discipline, Safety and Security Measures. The study revealed that all indicators of Security Policies and Procedures to wit; Miscellaneous Rules and Regulations, Norms and Decorum, and Disciplinary Measures are all significant, although respondents from Faculty/Personnel, and Students are significantly different to Client. Indicators of Security Risk Management Practices namely: Approach, Responsibilities, and Resources are all significant, although respondents from Faculty/Personnel and Students are significantly different to Client. Indicators of Security Measures namely: Preparedness, Efficiency, and Effectiveness are all significant, although respondents from Faculty/Personnel and Students are significantly different to Client. As to Preparedness, all indicators of security policies/procedures, security risk management practices are significantly related to its security measures the first four indicators show strong relationship as follow: Security Policies and Procedures Miscellaneous Rules and Regulations (r= $.732, p=<.01)$, Norms and Decorum $(r=.691, p=<.01)$, Disciplinary Measures $(r=.730, p=<.01)$, Security Risk Management Practices Approach $(r=.761, p=<.01)$ and the last two indicators shows very strong relationship as follows: Security Risk Management Practices Responsibilities $(r=.837, p=<.01)$ and Resources $(r=.810, p=<.01)$. Significance is clearly manifested by $p$ values that are all <.01 significance level. As to Efficiency, all indicators of security policies/procedures, risk management practices are significantly related to its security measures. The first four indicators show strong Security Policies/Procedures Miscellaneous Rules and Regulations $(r=.720, p=<.01)$, Norms and Decorum $(r=.702, p=<.01)$, Disciplinary Measures $(r=.724, p=<.01)$ Security Risk Management Practices Approach $(r=.761, p=<.01)$. The last two indicators shows very strong relationship as follows: Security Risk Management Practices Responsibilities $(r=.832, p=<.01)$, and Resources $(r=.810, p=<.01)$. Significance is clearly manifested by $p$ values that are all <.01 significance level. As to Effectiveness, all indicators of security policies/procedures, risk management practices are significantly related to its security measures. The first four indicators show strong Security Policies/Procedures Miscellaneous Rules and Regulations (r= .729, $p=<.01)$, Norms and Decorum $(r=.715, p=<.01)$, Disciplinary Measures $(r=.731, p=<.01)$ Security Risk Management Practices Approach $(r=.771, p=<.01)$. The last two indicators show very strong relationship as follows: Security Risk Management Practices Responsibilities $(r=.822, p=<.01)$, and Resources $(r=.819, p=<.01)$. Significance is clearly manifested by $p$ values that are all <.01 significance level.

INDEX TERMS: Security Risk Management, Approach, Responsibilities, Resources, Preparedness, Efficiency, Effectiveness
\end{abstract}




\section{BACKGROUND OF THE STUDY}

In the Philippines, corporal punishment is prohibited, following the issuance in 1974 of the Child and Youth Welfare Code (Presidential Decree No. 63, Article 59). (I think this is irrelevant) It prohibits any mental and physical violence against children. The school is where the youth/students spend most of their time for the purpose of preparing them for their future through formal education. Universities have different strategies in providing the students with the most conducive learning environment as possible, free from physical violence or harm. The effectiveness of an educational institution strategy should not go beyond what is legal as learning institutions, students and their clientele deserve the protection that any educational institution could provide.

As mandated by Senate Bill No. 1324 by Hon. Manuel "Manny" Villar, Jr. "An Act to Promote Crime Awareness and Security on Campuses", this bill empowers the state to gather precious data regarding the occurrence of crimes that happen to an educational institution (Section IV Disclosure of Campuses Security Policy and Campuses Crime Statistics). Statistics concerning the occurrence on campus, during the most recent school year, and during the two (2) preceding school years, are available, including, but not limited to the following criminal offenses reported to campus security authorities or local agencies. (murder; rape; robbery; aggravated

assault; sexual harassment; and motor vehicle theft) (Senate Bill 1342). This Senate Bill proves to be useful because all data gathered here could be the future reference in the creation of new guidelines that will be beneficiary to the welfare and protection of the students.

The primary goal of this study is to define the stakeholders' perception in the implementation of Laguna State Polytechnic University's Discipline, Safety and Security Measures, with the aim of helping the School Administrators to provide an enhanced Discipline, Safety and Security Measures to greatly benefit the school population.

\section{OBJECTIVES}

To evaluate the stakeholder's perception on the Laguna State Polytechnic University's Discipline, Safety and Security Measures. To know and identify the status of LSPU in terms of Security Policies and procedures and the Risk Management of this University.

To know the status of the Laguna State Polytechnic University's Security Policies and Procedures. To identify the significant between the independent and dependent variables.

\section{REVIEW OF RELATED LITERATURE}

Discipline, safety and security measures are important features of any Institution or Organization. Authorities and administrators are committed in assisting its clientele in providing a safe working environment for all its population. Great campus discipline, safety and security measures reduce crimes and support the organization mission.

Thornberg (2008) stresses that school rules are usually associated with classroom management and school discipline. However, rules also define ways of thinking about oneself and the world. Rules are guidelines for actions and for the evaluation of actions in terms of good and bad, or right and wrong, and therefore a part of moral or values education in school. Students' reasoning about rules varies across the rule categories. The perception of reasonable meaning behind a rule seems to be - not surprisingly significant to students' acceptance of the rule. According to the students, relational rules are the most important in school. Students also value protecting and structuring rules as important because of the meaning giving to them. Etiquette rules are valued as the least important or even unnecessary by the students.

Moreover, from the study of Momodu (2014) states that the tendency to flout library rules and regulations has become a common phenomenon amongst library users. The data is staggering and widespread, and the trend has failed to abate with its attendant consequences -man-hour, financial and material losses. This however, does not imply that there are no effective rules and regulations, but enforcing them has their own challenges. It was indeed obvious, that there are many administrative, logistic and legal challenges militating against effective 'policing' and enforcement of relevant library rules and regulations. It is recommended that key policies be put in place to ameliorate the challenges of library rule violations, while funding and training/retraining of staff should be enhanced.

On the other hand, Díaz-Vicario, et. al. (2017) says that schools should be safe spaces for students, teaching staff and non-teaching staff. For the concept of "safety" to be meaningful, it must be interpreted broadly to encompass well-being in its widest sense. A common challenge for schools and educational authorities is, therefore, to manage school safety appropriately not only to prevent physical accidents and incidents, but also with the purpose of creating an environment that promotes physical, emotional and social well-being, both individually and collectively.

From Grayson (2012) mentions that the primary job of any security program is to prevent crime. Crime prevention is a good beginning, but great security 
demands more. It must also deal with perception - the fear of crime. Great security programs reduce crime and support the organizational mission. They reduce actual risk along with the perception of risk and improve the organization's financial bottom line. When people feel safe and secure, learning improves, stress levels drop, sick days decrease while employee longevity increases. Feeling secure is a critical first step in the development of effective teams. Great security programs represent a true win-win opportunity for any organization.

Kim (2013) recommends that information security training be offered during the students' first semester in college. It may be a workshop during the incoming students' orientation or one class session of a required course for all first-year students. To develop the contents of training to fit students' needs, a university should assess students' understanding of information security awareness topics. Without having an assessment, training could be a one-size-fits-all approach, but that may not be effective and may be less attractive to students. Universities need to carefully monitored if students actually implement and follow what they learn. To monitor students' information security activities, a university can regularly survey its students or analyze hard data such as an information security incident reports, a help desk log file, hardware repair reports, or others.

In similar vein, Mewis, et. al. (2016) emphasize that no matter the mission of an organization is, the security of its facilities is critical. This is especially the case for education facilities, where so many students, staff and administrators spend the bulk of their days. Administrators have a moral and legal obligation to protect the people in their facilities. This can be accomplished with a proactive approach that identifies risk factors, establishes objectives and financial parameters, and results in a plan to carry out recommendations.

Booth, et. al. (2019) conclude that despite the importance of self-regulation for school readiness and success across the lifespan, little is known about children's conceptions of this important ability. Children depicted school as requiring regulation of their emotional, cognitive and behavioral responses. They characterized school as a dynamic setting, placing emphasis on the regulatory challenges of the outdoor environment. Children also described difficulties associated with navigating complex social interactions, often without assistance from external supports. The results inform strategies to support children's emerging self-regulation abilities.

Benson (2019) asserts that too many restrictions could hamper teens' individuality and resolve, as well as destroy relationships among school staff. Teenagers exist in a twilight zone of rights. Laws and regulations idiosyncratically define when it can be considered safe enough for a teen to exercise adult rights: to vote, to enlist in the military, to speak freely against authority, to wed, to drop out of school, to drive, to carry a gun, to have private conversations with medical providers, to watch certain movies.

Aviani (2006) stresses that in many middle schools, poor student lunchtime behavior is an ongoing problem. Such behavior can have a detrimental effect on a school's climate and culture, which can in turn degrade the quality of learning that occurs in the classroom. As a result, improving students' lunchtime behavior should be a priority for the staff. One solution is to make social skills instruction part of a school-wide discipline program. In many schools, administrators, teachers, support workers, and parents seek to create such programs through Effective Behavior Support (EBS). EBS is a positive and proactive approach to discipline problems in schools. The concept seeks to apply positive behavioral interventions and systems to bring about socially important change. For instance, EBS schools might seek to improve student behavior through environmental redesign, curriculum redesign, or the removal of rewards that inadvertently maintain problem behavior. The most successful interventions reinforce the values of students, parents, and educators.

Perkins, et. al. (2011) prove that bullying attitudes and behaviors and perceptions of peers were assessed in a case study experiment employing a social norms intervention in five diverse public middle schools in the State of New Jersey (Grades 6 to 8). In the baseline survey, students substantially misperceived peer norms regarding bullying perpetration and support for pro-bullying attitudes. As predicted by social norms theory, they thought bullying perpetration, victimization, and pro-bullying attitudes were far more frequent than was the case. Also as predicted, variation in perceptions of the peer norm for bullying was significantly associated with personal bullying perpetration and attitudes. Using print media posters as the primary communication strategy, an intervention displaying accurate norms from survey results was conducted at each of the five school sites. A pre-/postintervention comparison of results revealed significant reductions overall in perceptions of peer bullying and pro-bullying attitudes while personal bullying of others and victimization were also reduced and support for reporting bullying to adults at school and in one's family increased. The extent of reductions across school sites was associated with the prevalence and extent of recall of seeing poster messages reporting actual peer norms drawn from the initial survey data. 
Rates of change in bullying measures were highest (from around $17 \%$ to $35 \%$ ) for the school with the highest message recall by students after a one-and-ahalf-year intervention. Results suggest that a social norms intervention may be a promising strategy to help reduce bullying in secondary school populations.

Relatively, LaRusso (2008) says that positive school climates have been found to have favorable effects on adolescent health risk behaviors and mental health outcomes. However, the mechanisms by which teacher behavior may promote such effects in high schools have not been extensively studied. Based on social control theory and a social developmentalcontextual model, it was predicted that by respecting students' points of view and decision-making capabilities, teachers could help build respectful school climates that encourage healthy norms of behavior. Structural equation modeling with a nationally representative sample of 476 youth ages 14-18 supported the model. Adolescents who reported higher teacher support and regard for student perspectives in their high schools were more likely to see their schools as having respectful climates and healthy norms of drug use which was associated with lower levels of personal drug use. Students in such schools also reported greater social belonging and fewer symptoms of depression.

In the study of Galván, et. al. (2011) point out that the perceived norms were assessed by asking participants to estimate how many grade mates were academically engaged, disengaged, and antisocial. To capture social values, peer nominations were used to assess "coolness" associated with these behaviors. Perceived norms became gradually more negative from fall to spring and across grades four to eight. Whereas academic engagement was socially valued in elementary school, negative social and academic behaviors were valued in middle school. Additionally, improved social status was associated with increased academic engagement in fifth grade, disengagement in seventh and eighth grades, and antisocial behavior in sixth grade. The findings suggest that differences between elementary and middle school cultural norms and values may shed light on negative behavior changes associated with the transition to middle school.

Eisenberg, et. al. (2014) emphasize that identifying specific aspects of peer social norms that influence adolescent substance use may assist international prevention efforts. Descriptive social norms in the school context as a particularly important area to address in adolescent substance use prevention efforts.

Similarly, McCormick, et. al. (2014) conclude that a wide body of research has documented the relationship between social norms and individual behaviors. There is growing evidence that academic behaviors in early adolescence-when most children begin middle school-may be subject to normative influence as well. However, the structure and composition of peer relationships within middle schools have yet to be fully incorporated into current conceptualizations of academic norms. A social network approach that considers the structure of students' friendship networks can be a useful framework for informing understanding of middle school academic norms. This article integrates research and theory on social norms and social networks to introduce a model to improve understanding of academic norms in middle schools. Implications for future research are discussed.

\section{METHODOLOGY}

The research method used in this study was descriptive research design using questionnaires to analyze the impact of stakeholder's perception on the Laguna State Polytechnic University's Implementation of Discipline, Safety and Security Measures. Descriptive studies are usually the best methods for collecting information to demonstrate relationships and describe the world as it exists. Descriptive research aims to accurately and systematically describe a population, situation or phenomenon. It can answer what, when, where, when and how questions, but not why questions. To determine cause and effect, experimental research is required. A descriptive research design can use a wide variety of quantitative and qualitative methods to investigate one or more variables. Unlike in experimental research, the researcher does not control or manipulate any of the variables, but only observes and measures them. (McCombes, 2019).

The researcher gathered data from selfadministered questionnaires. Similarly, content analysis of the collected documentary material was done. Data gathering on the instruments to produce a reliable and valid statistics was done that helped in the attainment of such purpose.

\section{RESULTS AND DISCUSSIONS}

The major findings of the study followed the order in accordance with the statement of the problem namely (1) What is the status of the Laguna State Polytechnic University's Security Policies and Procedures in terms of its; Miscellaneous Rules and Regulation, Norms and Decorum, and Disciplinary Measures (2) What is the status of the Laguna State Polytechnic University's practices for Security Risk Management in terms of its; Approach, Responsibilities, and Resources (3) What is the status 
of the Laguna State Polytechnic University's Security Measures in terms of its; Preparedness, Efficiency, and Effectiveness (4) Is there a significant difference between the Faculty/Personnel, Students, and Visitors perception on the Laguna State Polytechnic University's Discipline, Safety and Security Measures?
The researcher used purposive sampling, in which the objective was to select typical or representative subject, the skills and judgment of the selected respondent were deliberately utilized. The questionnaire was given to the matrix of the target population that was represented in four (4) campuses of Laguna State Polytechnic University.

Table 1. Status of LSPU Security Policies and Procedures in terms of Miscellaneous Rules and Regulation Status of LSPU Security Policies and Procedures in terms of Miscellaneous Rules and Regulations

\begin{tabular}{|c|c|c|c|c|c|c|c|c|c|c|c|}
\hline \multirow{2}{*}{ Indicative Statement } & \multicolumn{3}{|c|}{$\begin{array}{l}\text { Faculty/ } \\
\text { Personnel }\end{array}$} & \multicolumn{3}{|c|}{ Student } & \multicolumn{3}{|c|}{ Client } & \multirow{2}{*}{ GM } & \multirow[t]{2}{*}{$\mathbf{R}$} \\
\hline & $\mathbf{M}$ & SD & $\mathbf{R}$ & $\mathbf{M}$ & SD & $\mathbf{R}$ & $\mathbf{M}$ & SD & $\mathbf{R}$ & & \\
\hline $\begin{array}{l}\text { Provides guidelines of } \\
\text { the security policies and } \\
\text { procedures. }\end{array}$ & 4.35 & 0.76 & SA & 4.13 & 0.78 & A & 4.51 & 0.69 & SA & 4.33 & SA \\
\hline $\begin{array}{l}\text { Explains the security } \\
\text { policies and procedures. }\end{array}$ & 4.12 & 0.86 & A & 3.16 & 0.86 & A & 4.31 & 0.83 & SA & 3.86 & A \\
\hline $\begin{array}{l}\text { Encourages faculty, } \\
\text { personnel, students, and } \\
\text { clients to form the } \\
\text { security policies and } \\
\text { procedures. }\end{array}$ & 4.18 & 0.90 & $\mathrm{~A}$ & 4.06 & 0.83 & A & 4.48 & 0.72 & SA & 4.24 & SA \\
\hline $\begin{array}{lr}\text { Utilizes necessary } \\
\text { resources in } \\
\text { implementing } & \text { the } \\
\text { security policies } & \text { and } \\
\text { procedures. } & \end{array}$ & 4.14 & 0.84 & $\mathrm{~A}$ & 4.06 & 0.89 & A & 4.38 & 0.69 & SA & 4.19 & A \\
\hline $\begin{array}{l}\text { 5. Regular updates when } \\
\text { deemed necessary }\end{array}$ & 4.06 & 0.99 & A & 3.87 & 0.96 & A & 4.46 & 0.79 & SA & 4.13 & A \\
\hline Overall Mean & 4.18 & S & & 4.02 & S & & 4.43 & VS & & 4.21 & VS \\
\hline
\end{tabular}

$$
\text { Legend: }
$$

$\begin{array}{lcc}\text { Scale } & \text { Range } & \text { Remark } \\ 5 & 4.20-5.00 & \text { Strongly Agree } \\ 4 & 3.40-4.19 & \text { Agree } \\ 3 & 2.60-3.39 & \text { Neutral } \\ 2 & 1.80-2.59 & \text { Disagree } \\ 1 & 1.00-1.79 & \text { Strongly Disagree }\end{array}$

Table 1 shows the status of LSPU security policies and procedures in terms of miscellaneous rules and regulation. It could be gleaned from the table that respondents strongly agree that the LSPU Security Management provides guidelines of the security policies and procedures $(M=4.33)$ and encourages faculty, personnel, students and clients to form the same $(M=4.24)$. On the other hand, respondents agree that the security policies and procedures are explained $(\mathrm{M}=3.86)$, utilize necessary resources in its implementation $(M=4.19)$, and updates policies when necessary $(M=4.13)$.

\section{Verbal Interpretation \\ Very Satisfactory \\ Satisfactory \\ Moderate Satisfactory \\ Fairly Satisfactory \\ Not Satisfactory}

The overall mean of 4.21 indicates that the LSPU Policies and Procedures as to Miscellaneous Rules and Regulation is very satisfactory.

Kwayu (2014) states that school rules and regulations need to be emphasized and given enough awareness so as to create harmony and cooperation among students and lead more students to become good citizens. School rules and regulations need to be emphasized and further studies are required to critically assess the content of school rules and recommend the best content that can produce quality citizenry. 
ISSN (Online): 2455-3662

EPRA International Journal of Multidisciplinary Research (IJMR) - Peer Reviewed Journal Volume: 7 | Issue: 3 | March 2021|| Journal DOI: 10.36713/epra2013 || SJIF Impact Factor 2021:7.147 ||ISI Value: 1.188

Table 2. Status of LSPU Security Policies and Procedures in terms of Norms and Decorum

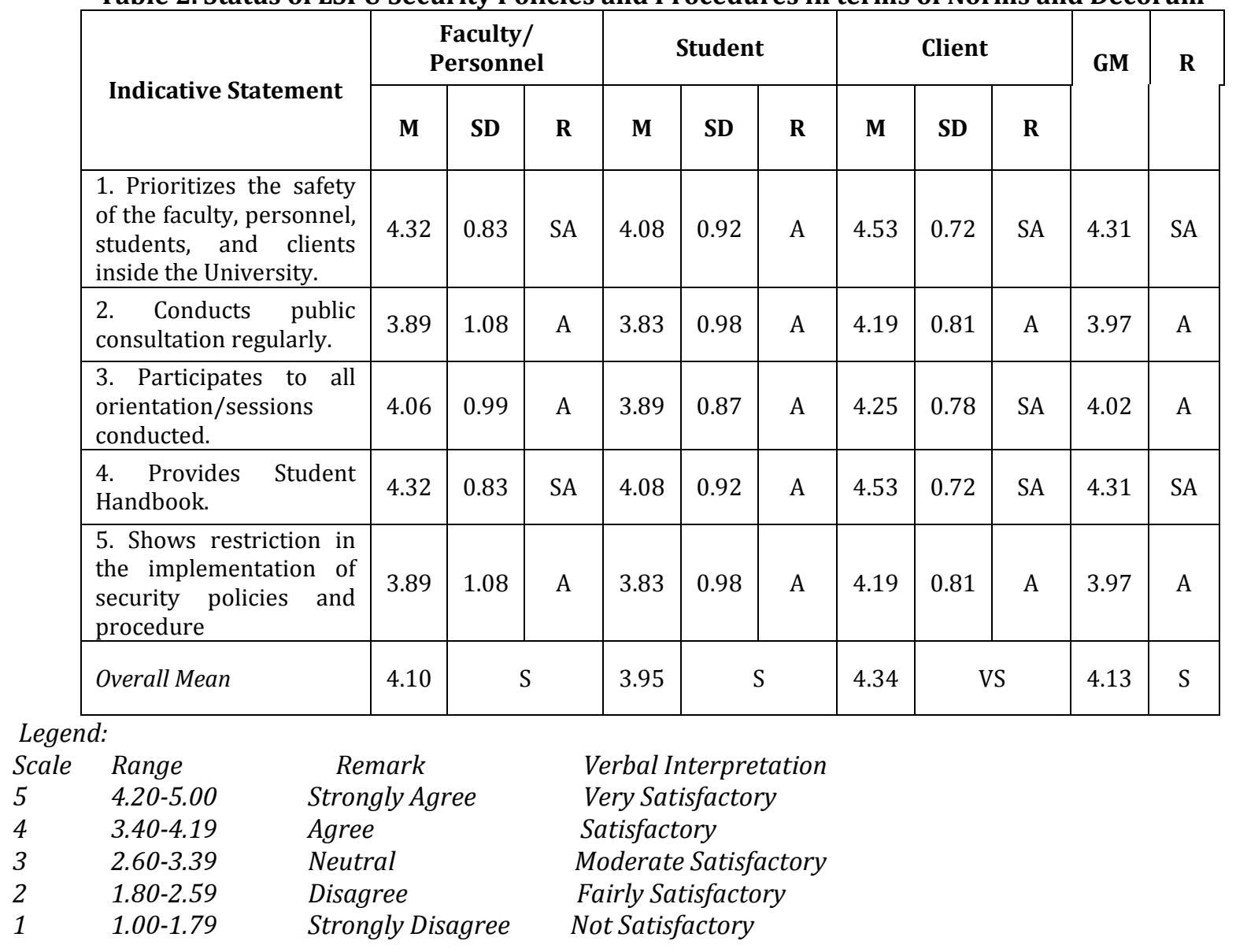

Table 2 shows the status of LSPU Policies and Procedures in terms of Norms and Decorum. It could be gleaned from the table that respondents strongly agree that the LSPU Security Management prioritizes the safety of the faculty, personnel, students, and clients inside the university $(M=4.31)$, and provides students handbook $(M=4.31)$. On the other hand, respondents agree that they conduct public consultation regularly $(\mathrm{M}=3.97)$, participates to all orientation/sessions conducted $(\mathrm{M}=4.02)$, and shows restriction in the implementation of security policies and procedures $(\mathrm{M}=3.97)$.
The overall mean of 4.13 indicates that the LSPU Policies and Procedures as to Norms and Decorum is Satisfactory.

The study of Melson (2012) supports the findings for it states that early intervention in schools to tackle alcohol problems is a widespread practice, despite patchy evidence of effectiveness. The 'Social norms' approach emerges from studies showing overestimation of 'others' consumption/approval of alcohol use amongst students. To correct such misperceptions of drinking norms, 'true' norms are fedback in order to modify perceptions, thus relieving possible social pressure to conform to the misperceived norms. 
ISSN (Online): 2455-3662

EPRA International Journal of Multidisciplinary Research (IJMR) - Peer Reviewed Journal

Volume: 7 | Issue: 3 | March 2021|| Journal DOI: 10.36713/epra2013 || SJIF Impact Factor 2021:7.147 ||ISI Value: 1.188

Table 3. Status of LSPU Security Policies and Procedures in terms of Disciplinary Measures Status of LSPU Security Policies and Procedures in terms of Disciplinary Measures

\begin{tabular}{|c|c|c|c|c|c|c|c|c|c|c|c|}
\hline \multirow{2}{*}{$\begin{array}{l}\text { Indicative } \\
\text { Statement }\end{array}$} & \multicolumn{3}{|c|}{$\begin{array}{c}\text { Faculty/ } \\
\text { Personnel }\end{array}$} & \multicolumn{3}{|c|}{ Student } & \multicolumn{3}{|c|}{ Client } & \multirow{2}{*}{ GM } & \multirow{2}{*}{$\mathbf{R}$} \\
\hline & M & SD & $\mathbf{R}$ & M & SD & $\mathbf{R}$ & M & SD & $\mathbf{R}$ & & \\
\hline $\begin{array}{l}\text { 1. Implements the } \\
\text { content of the } \\
\text { Student Handbook. }\end{array}$ & 4.19 & 0.91 & SA & 3.88 & 1.02 & A & 4.51 & 0.77 & SA & 4.19 & A \\
\hline $\begin{array}{l}\text { 2. Disseminates the } \\
\text { Student Handbook. }\end{array}$ & 4.24 & 0.87 & SA & 3.94 & 0.98 & A & 4.51 & 0.67 & SA & 4.23 & SA \\
\hline $\begin{array}{l}\text { 3. Question people } \\
\text { who enter the } \\
\text { property without } \\
\text { authorization. }\end{array}$ & 4.06 & 0.99 & A & 3.87 & 0.96 & A & 4.46 & 0.79 & SA & 4.13 & A \\
\hline $\begin{array}{l}\text { 4. Identify potential } \\
\text { treats }\end{array}$ & 4.32 & 0.83 & SA & 4.08 & 0.92 & A & 4.53 & 0.72 & SA & 4.31 & SA \\
\hline $\begin{array}{l}\text { 5. Ensure the safety } \\
\text { of people within the } \\
\text { school premises. }\end{array}$ & 3.89 & 1.08 & A & 3.83 & 0.98 & A & 4.19 & 0.81 & A & 3.7 & A \\
\hline Overall Mean & 4.14 & & & 3.92 & & & 4.44 & & & 4.16 & $S$ \\
\hline
\end{tabular}

\section{Legend:}

$\begin{array}{ll}\text { Scale } & \text { Range } \\ 5 & 4.20-5.00 \\ 4 & 3.40-4.19 \\ 3 & 2.60-3.39 \\ 2 & 1.80-2.59 \\ 1 & 1.00-1.79\end{array}$

Table 3 shows the status of LSPU Policies and Procedures in terms of Disciplinary Measures. It could be gleaned from the table that respondents strongly agree that the LSPU Security Management disseminates the student handbook $(M=4.23)$, and identify potential threats $(M=4.31)$. On the other hand, respondents agree that the LSPU Security Management implements the content of the handbook $(M=4.19)$, question people who enter the property without authorization $(M=4.13)$, and ensure the safety of the people within the school premises $(M=3.7)$.

$\begin{array}{ll}\quad \text { Remark } & \text { Verbal Interpretation } \\ \text { Strongly Agree } & \text { Very Satisfactory } \\ \text { Agree } & \text { Satisfactory } \\ \text { Neutral } & \text { Moderate Satisfactory } \\ \text { Disagree } & \text { Fairly Satisfactory } \\ \text { Strongly Disagree } & \text { Not Satisfactory }\end{array}$

The overall mean of 4.14 indicates that the LSPU Policies and Procedures as to Disciplinary Measures is satisfactory.

Venter (2016) mentions that in general, urban schools across the nation rely on suspensions, reprimands, withholding of privileges, and/or expulsion as the means of discipline. Unfortunately, these reactive procedures only help a small number of children learn to "comply with general expectations" and are insufficient for many students who exhibit more challenging behavior problems.

Table 4. Status of LSPU Implementation for Security Risk Management in terms of Approach

\begin{tabular}{|c|c|c|c|c|c|c|c|c|c|c|c|}
\hline \multirow[t]{2}{*}{ Indicative Statement } & \multicolumn{3}{|c|}{$\begin{array}{c}\text { Faculty/ } \\
\text { Personnel }\end{array}$} & \multicolumn{3}{|c|}{ Student } & \multicolumn{3}{|c|}{ Client } & \multirow{2}{*}{ GM } & \multirow{2}{*}{$\mathbf{R}$} \\
\hline & $\mathbf{M}$ & SD & $\mathbf{R}$ & $\mathbf{M}$ & SD & $\mathbf{R}$ & $\mathbf{M}$ & SD & $\mathbf{R}$ & & \\
\hline $\begin{array}{l}\text { 1. Identifies possible risk and } \\
\text { threats. }\end{array}$ & 4.13 & 0.88 & A & 3.97 & 0.78 & A & 4.40 & 0.68 & SA & 4.16 & A \\
\hline $\begin{array}{l}\text { 2. Identifies possible counter } \\
\text { measures. }\end{array}$ & 4.13 & 0.88 & A & 3.82 & 0.82 & A & 4.33 & 0.65 & SA & 4.09 & A \\
\hline $\begin{array}{l}\text { 3. Identifies vulnerability to the } \\
\text { information resources. }\end{array}$ & 4.11 & 0.91 & A & 3.93 & 0.82 & A & 4.37 & 0.65 & SA & 4.13 & A \\
\hline $\begin{array}{l}\text { 4.Recommend corrective } \\
\text { measures }\end{array}$ & 4.32 & 0.83 & A & 4.08 & 0.92 & A & 4.53 & 0.72 & SA & 4.31 & SA \\
\hline $\begin{array}{l}\text { 5.Communication among } \\
\text { stakeholders should be clear and } \\
\text { open }\end{array}$ & 3.89 & 1.08 & A & 3.83 & 0.98 & A & 4.19 & 0.81 & A & 3.97 & A \\
\hline Overall Mean & 4.12 & & & 3.93 & Tha & & 4.36 & & & 4.13 & $\mathrm{~S}$ \\
\hline
\end{tabular}


Legend:

$\begin{array}{llll}\text { Scale } & \text { Range } & \text { Remark } & \text { Verbal Interpretation } \\ 5 & 4.20-5.00 & \text { Strongly Agree } & \text { Very Satisfactory } \\ 4 & 3.40-4.19 & \text { Agree } & \text { Satisfactory } \\ 3 & 2.60-3.39 & \text { Neutral } & \text { Moderate Satisfactory } \\ 2 & 1.80-2.59 & \text { Disagree } & \text { Fairly Satisfactory } \\ 1 & 1.00-1.79 & \text { Strongly Disagree } & \text { Not Satisfactory }\end{array}$

Table 4 shows the status of LSPU Practices for Security Risk Management in terms of Approach. It could be gleaned from the table that respondents strongly agree that the LSPU Security Management recommended corrective measures $(M=4.31)$. On the other hand, respondents agree that LSPU Security Management identifies possible risk and threats $(M=4.16)$, identifies possible counter measures $(M=4.09)$, identifies vulnerability to the information resources $(M=4.13)$, and communication among stakeholders should be clear and open $(M=3.97)$.

The overall mean of 4.13 indicates that the LSPU Practices for Security Risk Management as to Approach is satisfactory.

Students sometimes feel reluctant to report crimes on campus because they are uncertain of how the campus security personnel will handle the information. In order to prevent any negativity regarding the handling of crime, some will choose not to report crimes. Dangerous situations in campus are oftentimes an indicator of a lack of supportive safety culture. An open proactive approach to identifying and mitigating risk is crucial to building a safety culture in which members' perceptions are positive. Beard, (2010).

In addition to administration-based initiatives, students should also take an active role in participation and promotion of the safety of their communities. Many higher education leaders believe college campuses should encourage their student to become more community-oriented in order to promote and foster a society as becoming more involved in celebrating the dignity of each fellow individual person. Administrators should create more programs that involve the engagement of students with one another to help foster relationships and social acceptance. A campus culture that has been shown to promote the overall good in the community can be a contributing factor to the safety climate of a university campus. Zuckerman, (2010).

Table 5. Status of LSPU Implementation for Security Risk Management in terms of Responsibilities

\begin{tabular}{|c|c|c|c|c|c|c|c|c|c|c|c|c|}
\hline \multirow{2}{*}{\multicolumn{2}{|c|}{ Indicative Statement }} & \multicolumn{3}{|c|}{$\begin{array}{l}\text { Faculty/ } \\
\text { Personnel }\end{array}$} & \multicolumn{3}{|c|}{ Student } & \multicolumn{3}{|c|}{ Client } & \multirow{2}{*}{ GM } & \multirow[t]{2}{*}{$\mathbf{R}$} \\
\hline & & $\mathbf{M}$ & SD & $\mathbf{R}$ & $\mathbf{M}$ & SD & $\mathbf{R}$ & $\mathbf{M}$ & SD & $\mathbf{R}$ & & \\
\hline \multicolumn{2}{|c|}{$\begin{array}{l}\text { 1. Provides a risk } \\
\text { management framework. }\end{array}$} & 4.02 & 0.90 & A & 3.83 & 0.83 & A & 4.36 & 0.63 & SA & 4.07 & A \\
\hline \multicolumn{2}{|c|}{$\begin{array}{l}\text { 2. Explains the } \\
\text { responsibility of the risk } \\
\text { management framework. }\end{array}$} & 4.00 & 0.93 & A & 3.98 & 0.88 & A & 4.30 & 0.76 & SA & 4.09 & A \\
\hline \multicolumn{2}{|c|}{$\begin{array}{l}\text { 3. Implements plans to the } \\
\text { risk and threats. }\end{array}$} & 4.38 & 0.85 & SA & 3.91 & 0.85 & A & 4.40 & 0.75 & SA & 4.23 & SA \\
\hline \multicolumn{2}{|c|}{$\begin{array}{l}\text { 4. Provides Standard } \\
\text { Operating Procedure. }\end{array}$} & 4.13 & 0.93 & A & 3.88 & 0.97 & A & 4.37 & 0.67 & SA & 4.12 & A \\
\hline \multicolumn{2}{|c|}{$\begin{array}{l}\text { 5. Advise every one of } \\
\text { security and safety } \\
\text { precautions that should be } \\
\text { taken. }\end{array}$} & 4.06 & 1.01 & A & 3.94 & 0.94 & A & 4.29 & 0.69 & SA & 4.09 & A \\
\hline \multicolumn{2}{|c|}{ Overall Mean } & 4.12 & $\mathrm{~S}$ & & 3.91 & $\mathrm{~S}$ & & 4.34 & VS & & 4.12 & $\mathrm{~S}$ \\
\hline \multicolumn{13}{|c|}{ Legend: } \\
\hline $\begin{array}{l}\text { Scale } \\
5\end{array}$ & $\begin{array}{l}\text { Range } \\
4.20-5.00\end{array}$ & \multicolumn{2}{|c|}{ Strongly Agree } & & \multicolumn{3}{|c|}{ Verbal Interpretation } & & & & & \\
\hline 4 & $3.40-4.19$ & \multicolumn{3}{|c|}{ Agree } & \multicolumn{3}{|c|}{ Satisfactory } & & & & & \\
\hline 3 & $2.60-3.39$ & \multicolumn{3}{|l|}{ Neutral } & \multicolumn{3}{|c|}{ Moderate Satisfactory } & & & & & \\
\hline 2 & $1.80-2.59$ & \multicolumn{3}{|c|}{ Disagree } & \multicolumn{3}{|c|}{ Fairly Satisfactory } & & & & & \\
\hline 1 & $1.00-1.79$ & \multicolumn{3}{|c|}{ Strongly Disagree } & \multicolumn{3}{|c|}{ Not Satisfactory } & & & & & \\
\hline
\end{tabular}


Table 5 shows Practices for Security Risk Management in terms of Responsibilities. It could be gleaned from the table that respondents strongly agree that the LSPU Security Management implement plans to the risk and threats $(M=4.23)$. On the other hand, respondents agree that they provide risk management framework $(M=4.07)$, explains the responsibility of the risk management framework $(M=4.09)$, provides standard operating procedure $(M=4.12)$, and advise everyone of security and safety precautions that should be taken $(M=4.09)$.
The overall mean of 4.12 indicates that the LSPU Implementation for Security Risk Management as to Responsibilities is satisfactory.

Mangena (2010) points out that Schools in this day and age are compelled to market and transform themselves into winning, compelling and powerful brands. In the past. schools enjoyed the geographic and racial monopoly over parents and learner choice of a school. With the advent of the democratic dispensation the survival of a school needs a scientific and commercial praxis of concepts like branding. Branding itself holds a host of benefits for all the stakeholders in a school.

Table 6. Status of LSPU Implementation for Security Risk Management in terms of Resources

\begin{tabular}{|c|c|c|c|c|c|c|c|c|c|c|c|}
\hline \multirow{2}{*}{ Indicative Statement } & \multicolumn{3}{|c|}{$\begin{array}{l}\text { Faculty/ } \\
\text { Personnel }\end{array}$} & \multicolumn{3}{|c|}{ Student } & \multicolumn{3}{|c|}{ Client } & \multirow{2}{*}{ GM } & \multirow{2}{*}{$\mathbf{R}$} \\
\hline & $\mathbf{M}$ & SD & $\mathbf{R}$ & $\mathbf{M}$ & SD & $\mathbf{R}$ & $\mathbf{M}$ & SD & $\mathbf{R}$ & & \\
\hline $\begin{array}{l}\text { 1. Provides adequate } \\
\text { security personnel/forces. }\end{array}$ & 4.22 & 0.84 & SA & 3.84 & A & A & 4.38 & 0.65 & SA & 4.14 & A \\
\hline $\begin{array}{l}\text { 2. Provides adequate } \\
\text { surveillance equipment. }\end{array}$ & 4.16 & 0.84 & A & 3.88 & A & A & 4.30 & 0.68 & SA & 4.11 & A \\
\hline $\begin{array}{l}\text { 3. Provides adequate } \\
\text { communication equipment. }\end{array}$ & 4.13 & 0.85 & A & 3.91 & A & A & 4.33 & 0.69 & SA & 4.12 & A \\
\hline $\begin{array}{l}\text { 4. Has enough resources to } \\
\text { manage risk on a continuing } \\
\text { basis }\end{array}$ & 4.32 & 0.83 & SA & 4.08 & A & A & 4.53 & 0.72 & SA & 4.31 & SA \\
\hline $\begin{array}{l}\text { 5. Recognize information } \\
\text { resources as essential } \\
\text { organizational asset }\end{array}$ & 3.89 & 1.08 & A & 3.83 & A & A & 4.19 & 0.81 & A & 3.97 & A \\
\hline Overall Mean & 4.14 & & & 3.91 & & & 4.35 & & & 4.13 & $S$ \\
\hline
\end{tabular}

\section{Legend:}

Scale Range

$5 \quad 4.20-5.00$

$4 \quad 3.40-4.19$

$3 \quad 2.60-3.39$

$2 \quad 1.80-2.59$

$1 \quad 1.00-1.79$

$\quad$ Remark
Strongly Agree
Agree
Neutral
Disagree
Strongly Disagree

Table 6 shows Practices for Security Risk Management in terms of Resources. It could be gleaned from the table that respondents strongly agree that the LSPU Security Management has enough resources to manage risk on a continuing basis $(M=4.31)$. On the other hand, respondents agree that LSPU Security Management provide adequate security personnel/forces $(M=4.14)$, provides adequate surveillance equipment $(M=4.11)$, provides adequate communication equipment $(M=4.12)$, and recognize information resources as essential organizational asset $(M=3.97)$.

\author{
Verbal Interpretation \\ Fairly Satisfactory \\ Not Satisfactory
}

The overall mean of 4.13 indicates that the LSPU Implementation for Security Risk Management as to Resources is satisfactory.

As the need for a more reliable facility in security management, funding is one key element that will dictate the preparedness of each institution. The better the allotment of funds provided, the better the equipment and facilities. Likewise, the better training for each security personnel the better the quality of service of each security personnel could provide. As some researches also demonstrated on the effect of certain variables had on students' overall perception of campus safety as the study of the variables included student demographics, the presence and type of security 
personnel, and the rurality of the campus setting. Patton, (2010).

A lack of budgetary resources was cited as a barrier for improving campus safety. Although administrators indicated that there were plans to improve, the effect of this commitment to campus safety appears to have had an effect on the students who were attending the campus. Patton, et. al. (2016).

Bodalina (2013) asserts that the educators agree that the governing body effectively manage and effectively procure resources for the school. There was only partial agreement that the Provincial Education Department provides physical resources adequately. It was found that governing bodies and school management teams needed to be provided with continual training by the Provincial Education Department. Furthermore, it appears that whilst structures and processes are established to manage physical resources, there is need to constantly appraise and review their functionality. In order to promote effective management of physical resources, a fully functional asset management committee must be established at all schools that would meet regularly to assess the functionality of all structures and processes in line with the asset management policy. There is also an acute need for the Provincial Education Department to build storerooms with improved security in order to preserve the assets at all public schools by factoring into their provincial budgets.

Table 7. Status of LSPU Implementation of Security Measures in terms of Preparedness

\begin{tabular}{|c|c|c|c|c|c|c|c|c|c|c|c|}
\hline \multirow{3}{*}{ Indicative Statement } & \multirow{2}{*}{\multicolumn{3}{|c|}{$\begin{array}{c}\text { Faculty/ } \\
\text { Personnel }\end{array}$}} & \multirow{2}{*}{\multicolumn{3}{|c|}{ Student }} & \multirow{2}{*}{\multicolumn{3}{|c|}{ Client }} & \multirow{3}{*}{ GM } & \multirow{3}{*}{$\mathbf{R}$} \\
\hline & & & & & & & & & & & \\
\hline & $\mathbf{M}$ & SD & $\mathbf{R}$ & M & SD & $\mathbf{R}$ & $\mathbf{M}$ & SD & $\mathbf{R}$ & & \\
\hline $\begin{array}{l}\text { Creates an Emergency } \\
\text { Response Team. }\end{array}$ & 4.06 & 1.01 & A & 3.94 & 0.94 & A & 4.29 & 0.69 & SA & 4.09 & A \\
\hline $\begin{array}{l}\text { Aware on the LSPU } \\
\text { Emergency } \\
\text { Procedure/Plan. }\end{array}$ & 4.08 & 1.03 & A & 3.88 & 0.86 & A & 4.33 & 0.74 & SA & 4.09 & A \\
\hline $\begin{array}{l}\text { Makes tools and } \\
\text { equipment readily } \\
\text { available for Emergency } \\
\text { Response Team. }\end{array}$ & 4.09 & 0.99 & A & 3.95 & 0.90 & A & 4.36 & 0.73 & SA & 4.13 & A \\
\hline $\begin{array}{l}\text { Utilizes necessary } \\
\text { resources in } \\
\text { implementing risk } \\
\text { management framework. }\end{array}$ & 4.03 & 0.95 & A & 3.83 & 0.89 & A & 4.24 & 0.77 & SA & 4.03 & A \\
\hline $\begin{array}{l}\text { 5. Carry out problems in } \\
\text { the most immediate } \\
\text { action in a short span of } \\
\text { time. }\end{array}$ & 4.06 & 1.01 & A & 3.94 & 0.94 & A & 4.29 & 0.69 & SA & 4.09 & A \\
\hline Overall Mean & 4.06 & & & 3.91 & & & 4.30 & & & 4.09 & $\mathrm{~S}$ \\
\hline
\end{tabular}

Legend:

Scale

$5 \quad 4.20-5.00$

$4 \quad 3.40-4.19$

$3 \quad 2.60-3.39$

$2 \quad 1.80-2.59$

$1 \quad 1.00-1.79$

Remark
Strongly Agree
Agree
Neutral
Disagree
Strongly Disagree

\section{Verbal Interpretation \\ Very Satisfactory \\ Satisfactory \\ Moderate Satisfactory \\ Fairly Satisfactory \\ Not Satisfactory}

Table 7 shows status of LSPU Security Measures in terms of Preparedness. It could be gleaned from the table that respondents agree that the LSPU Security Management creates emergency response team $(M=4.09)$, aware on the LSPU emergency procedure/plan $(M=4.09)$, makes tools and equipment readily available for emergency response team $(M=4.13)$, utilizes necessary resources in implementing risk management framework $(M=4.03)$, and carry out problems in the most immediate action in a short span of time $(M=4.09)$.

The overall mean of 4.13 indicates that the LSPU Implementation of Security Measures as to preparedness is satisfactory.

Van Jaarsveld, (2011) stresses that the needs of school security have changed over the years from an emphasis on protecting school property (vandalism, fire or theft), to the safety of the scholars and the educators. 
ISSN (Online): 2455-3662

EPRA International Journal of Multidisciplinary Research (IJMR) - Peer Reviewed Journal Volume: 7 | Issue: 3 | March 2021|| Journal DOI: 10.36713/epra2013 || SJIF Impact Factor 2021:7.147 ||ISI Value: 1.188

Currently school security requires well-developed security and safety plans, as well as undertaking proper

risk assessment and threat analysis exercises.

Table 8. Status of LSPU Implementation of Security Measures in terms of Efficiency

\begin{tabular}{|c|c|c|c|c|c|c|c|c|c|c|c|}
\hline \multirow{2}{*}{ Indicative Statement } & \multicolumn{3}{|c|}{$\begin{array}{l}\text { Faculty/ } \\
\text { Personnel }\end{array}$} & \multicolumn{3}{|c|}{ Student } & \multicolumn{3}{|c|}{ Client } & \multirow{2}{*}{ GM } & \multirow[t]{2}{*}{$\mathbf{R}$} \\
\hline & $\mathbf{M}$ & SD & $\mathbf{R}$ & $\mathbf{M}$ & SD & $\mathbf{R}$ & $\mathbf{M}$ & SD & $\mathbf{R}$ & & \\
\hline $\begin{array}{l}\text { 1. Provides Emergency } \\
\text { Procedure/Plan }\end{array}$ & 4.02 & 1.03 & A & 3.89 & 0.91 & A & 4.39 & 0.77 & SA & 4.1 & A \\
\hline $\begin{array}{l}\text { 2. Provides hazard free } \\
\text { facilities. }\end{array}$ & 4.02 & 1.05 & A & 3.83 & 1.00 & A & 4.42 & 0.69 & SA & 4.09 & A \\
\hline $\begin{array}{l}\text { 3. Provides a sufficient } \\
\text { Emergency Tools and } \\
\text { Equipment. }\end{array}$ & 3.98 & 1.07 & A & 3.89 & 1.00 & A & 4.37 & 0.79 & SA & 4.09 & A \\
\hline $\begin{array}{l}\text { 4. Provides a sufficient } \\
\text { Emergency Response Team. }\end{array}$ & 4.05 & 1.05 & A & 3.84 & 0.99 & A & 4.41 & 0.73 & SA & 4.1 & A \\
\hline $\begin{array}{l}\text { 5. Has security guards who } \\
\text { are always on the alert } \\
\text { when needs arises }\end{array}$ & 4.06 & 1.01 & A & 3.94 & 0.94 & A & 4.29 & 0.69 & SA & 4.09 & A \\
\hline Overall Mean & 4.03 & & & 3.88 & & & 4.38 & & & 4.09 & $S$ \\
\hline
\end{tabular}

Legend:

Scale Range

$5 \quad 4.20-5.00$

$4 \quad 3.40-4.19$

$3 \quad 2.60-3.39$

$2 \quad 1.80-2.59$

$1 \quad 1.00-1.79$

Remark
Strongly Agree
Agree
Neutral
Disagree
Strongly Disagree

Table 8 shows status of LSPU Security Measures in terms of Efficiency. It could be gleaned from the table that respondents agree that the LSPU Security Management provides emergency procedure/plan $(M=4.1)$, provides hazard free facilities $(M=4.09)$, provides a sufficient emergency tools and equipment $(M=4.09)$, provides a sufficient emergency response team $(M=4.1)$, and has security guards who are always in alert when need arises $(M=4.09)$.

The overall mean of 4.09 indicates that the LSPU Implementation of Security Measures as to efficiency is satisfactory.

The overall appearance of a campus can speaks volumes about how safe a campus really is. The

Verbal Interpretation
Very Satisfactory
Satisfactory
Moderate Satisfactory
Fairly Satisfactory
Not Satisfactory

perception of safety may not always be accurately displayed in public reports which are made available to all for viewing due to the fear of reporting or the fear of publicity, but there are many other ways beyond public reporting to assess the campus choice. Trust, (2013).

Although the perceptions of campus safety a student or parent may have are not necessarily and indicator of the level of danger, which is present, it is imperative that campus administrators realize the importance of students feeling safe as well as actually being safe. Fear of the perceived threat of danger can ultimately have an adverse effect on students' emotional health which will limit their personal and educational success. Trust, (2013). 
ISSN (Online): 2455-3662

EPRA International Journal of Multidisciplinary Research (IJMR) - Peer Reviewed Journal

Volume: 7 | Issue: 3 | March 2021|| Journal DOI: 10.36713/epra2013 || SJIF Impact Factor 2021:7.147 ||ISI Value: 1.188

Table 9. Status of LSPU Implementation of Security Measures in terms of Effectiveness

\begin{tabular}{|c|c|c|c|c|c|c|c|c|c|c|c|}
\hline \multirow{2}{*}{ Indicative Statement } & \multicolumn{3}{|c|}{$\begin{array}{c}\text { Faculty/ } \\
\text { Personnel } \\
\end{array}$} & \multicolumn{3}{|c|}{ Student } & \multicolumn{3}{|c|}{ Client } & \multirow[t]{2}{*}{ GM } & \multirow[t]{2}{*}{$\mathbf{R}$} \\
\hline & $\mathbf{M}$ & SD & $\mathbf{R}$ & $\mathbf{M}$ & SD & $\mathbf{R}$ & $\mathbf{M}$ & SD & $\mathbf{R}$ & & \\
\hline $\begin{array}{l}\text { 1. Conducts a regular } \\
\text { Emergency Drills/Exercises. }\end{array}$ & 4.16 & 0.84 & A & 3.98 & 0.88 & A & 4.43 & 0.67 & SA & 4.19 & A \\
\hline $\begin{array}{l}\text { 2. Conducts building audit } \\
\text { security. }\end{array}$ & 3.98 & 1.07 & A & 3.89 & 0.91 & A & 4.49 & 0.66 & SA & 4.12 & A \\
\hline $\begin{array}{l}\text { 3. Security guards are posted } \\
\text { accordingly to places that } \\
\text { needs close monitoring }\end{array}$ & 4.02 & 1.03 & A & 3.89 & 0.91 & A & 4.39 & 0.77 & SA & 4.1 & A \\
\hline $\begin{array}{l}\text { 4. CCTVs are placed in } \\
\text { strategic areas }\end{array}$ & 4.02 & 1.05 & A & 3.83 & 1.00 & A & 4.42 & 0.69 & SA & 4.09 & A \\
\hline $\begin{array}{l}\text { 5. Sensitive information are } \\
\text { well kept }\end{array}$ & 3.98 & 1.07 & A & 3.89 & 1.00 & A & 4.37 & 0.79 & SA & 4.08 & A \\
\hline Overall Mean & 4.03 & & & 3.90 & & & 4.42 & & & 4.11 & $S$ \\
\hline
\end{tabular}

Legend:

Scale Range

$5 \quad 4.20-5.00$

$4 \quad 3.40-4.19$

$3 \quad 2.60-3.39$

$1.80-2.59$

Remark

Strongly Agree

Agree

Neutral

Disagree

Strongly Disagree

\section{Verbal Interpretation \\ Very Satisfactory \\ Satisfactory \\ Moderate Satisfactory \\ Fairly Satisfactory \\ Not Satisfactory}

Table 9 shows status of LSPU Implementation of Security Measures in terms of Effectiveness. It could be gleaned from the table that respondents agree that the LSPU Security Management conducts a regular emergency drills/exercises $(M=4.19)$, conducts building audit security $(M=4.12)$, security guards are posted accordingly to places that needs close monitoring $(M=4.1)$, cctvs are placed in strategic areas $(M=4.09)$, and sensitive information are well kept $(M=4.08)$.

The overall mean of 4.11 indicates that the LSPU Implementation of Security Measures as to effectiveness is satisfactory.

Bott (2015) states that organizations today face a myriad of security risks given their increased use of information technology. New solutions to improve information security within organizations large and small need to be researched and analyzed. Review of relevant literature has determined that although organizations are managing security from the top down, there is a lack of security management at the project level and that most project managers and their teams rely on the organizational security measures to keep information secure. The concept of managing security risks at the project level is not well defined and there exists no concrete and widely accepted framework for it.

Table 10. Significant Difference in the Assessment by Three Groups of Respondents

\begin{tabular}{|l|c|c|c|c|c|c|}
\hline \multirow{2}{*}{ Indicator } & \multicolumn{3}{c|}{ Group Mean } & \multirow{2}{*}{ F } & p & \multirow{2}{*}{ Analysis } \\
\cline { 2 - 6 } & $\begin{array}{c}\text { Faculty/ } \\
\text { Personnel }\end{array}$ & Student & Client & & & \\
\hline $\begin{array}{l}\text { Security Policies and Procedures } \\
\text { Miscellaneous Rules and Regulations }\end{array}$ & $4.18 b$ & $4.02 b$ & $4.43 a$ & 10.54 & $<.01$ & Significant \\
$\begin{array}{l}\text { Norms and Decorum } \\
\text { Disciplinary Measures }\end{array}$ & $4.10 b$ & $3.94 b$ & $4.34 a$ & 7.43 & $<.01$ & Significant \\
& $4.14 b$ & $3.92 b$ & $4.44 a$ & 15.22 & $<.01$ & Significant \\
\hline Security Risk Management & & & & & & \\
$\begin{array}{l}\text { Practices } \\
\text { Approach } \\
\text { Responsibilities }\end{array}$ & $4.12 b$ & $3.39 b$ & $4.36 a$ & 11.71 & $<.01$ & Significant \\
& $4.05 b$ & $3.91 b$ & $4.34 a$ & 10.94 & $<.01$ & Significant \\
\hline
\end{tabular}


ISSN (Online): 2455-3662

EPRA International Journal of Multidisciplinary Research (IJMR) - Peer Reviewed Journal Volume: 7 | Issue: 3 | March 2021|| Journal DOI: 10.36713/epra2013 || SJIF Impact Factor 2021:7.147 ||ISI Value: 1.188

\begin{tabular}{|l|c|c|c|c|c|c|}
\hline Resources & $4.14 a$ & $3.91 b$ & $4.35 a$ & 12.00 & $<.01$ & Significant \\
\hline Security Measures & & & & & & \\
Preparedness & $4.06 a b$ & $3.91 b$ & $4.30 a$ & 7.33 & $<.01$ & Significant \\
Efficiency & $4.03 b$ & $3.88 b$ & $4.38 a$ & 11.40 & $<.01$ & Significant \\
Effectiveness & $4.03 b$ & $3.90 b$ & $4.42 a$ & 14.14 & $<.01$ & Significant \\
\hline
\end{tabular}

Means that do not share a letter are significantly different.

Table 10 reveals that all indicators of Security Policies and Procedures namely: Miscellaneous Rules and Regulations, Norms and Decorum, and Disciplinary Measures are all significant, although respondents from Faculty/Personnel, and Students are significantly different to client. Indicators of Security Risk Management Practices namely: Approach,
Responsibilities, and Resources are all significant, although respondents from Faculty/Personnel and Students are significantly different to client. Indicators of Security Measures namely: Preparedness, Efficiency, and Effectiveness are all significant, although respondents from Faculty/Personnel and Students are significantly different to client.

Table 11. Significant Relation between Security Policies/Procedures, Risk Management Practices and Security Measures in Terms of Preparedness

\begin{tabular}{|l|c|c|c|c|}
\hline \multicolumn{1}{|c|}{ Indicator } & $\mathbf{r}$ & Interpretation & $\boldsymbol{p}$ & Analysis \\
\hline $\begin{array}{l}\text { Security Policies and } \\
\text { Procedures }\end{array}$ & & & & \\
$\begin{array}{l}\text { Miscellaneous Rules } \\
\text { and Regulations }\end{array}$ & .732 & Strong & $<.01$ & Significant \\
Norms and Decorum & .691 & Strong & $<.01$ & Significant \\
$\quad$ Disciplinary & .730 & Strong & $<.01$ & Significant \\
Measures & & & & \\
Security Risk & & & & \\
Management Practices & .761 & Strong & $<.01$ & Significant \\
Approach & .837 & Very Strong & $<.01$ & Significant \\
Responsibilities & .810 & Very Strong & $<.01$ & Significant \\
$\quad$ Resources &
\end{tabular}

Table 11 reveals that all indicators of security policies/procedures, security risk management practices are significantly related to its security measures the first four indicators show strong relationship as follow: Security Policies and Procedures Miscellaneous Rules and Regulations $(\mathrm{r}=.732, \mathrm{p}=<.01)$, Norms and Decorum $(\mathrm{r}=.691, \mathrm{p}=<.01)$, Disciplinary Measures $(\mathrm{r}=$ $.730, p=<.01)$, Security Risk Management Practices Approach $(\mathrm{r}=.761, \mathrm{p}=<.01)$ and the last two indicators shows very strong relationship as follows: Security
Risk Management Practices Responsibilities $(\mathrm{r}=.837$, $\mathrm{p}=<.01)$ and Resources $(\mathrm{r}=.810, \mathrm{p}=<.01)$. Significance is clearly manifested by $\mathrm{p}$ values that are all $<.01$ significance level.

On the other hand, of the six indicators of security policies and procedures and security risk management practices responsibilities and resources got very strong interpretation/remarks. It means that respondents perceived it as the most highly rated indicator as far as preparedness is concern. 
ISSN (Online): 2455-3662

EPRA International Journal of Multidisciplinary Research (IJMR) - Peer Reviewed Journal

Volume: 7 | Issue: 3 | March 2021|| Journal DOI: 10.36713/epra2013 || SJIF Impact Factor 2021:7.147 ||ISI Value: 1.188

Table 12. Significant Relation between the Implementation of Security Policies/Procedures, Risk Management Practices and Security Measures in Terms of Efficiency

\begin{tabular}{|l|c|c|c|c|}
\hline \multicolumn{1}{|c|}{ Indicator } & $\mathbf{r}$ & Interpretation & $\boldsymbol{p}$ & Analysis \\
\hline $\begin{array}{l}\text { Security Policies and } \\
\text { Procedures }\end{array}$ & & & & \\
$\begin{array}{l}\text { Miscellaneous Rules } \\
\text { and Regulations }\end{array}$ & .720 & Strong & $<.01$ & Significant \\
$\begin{array}{l}\text { Norms and Decorum } \\
\text { Disciplinary }\end{array}$ & .702 & Strong & $<.01$ & Significant \\
Measures & .724 & Strong & $<.01$ & Significant \\
\hline Security Risk & & & & \\
Management & & & & \\
Practices & .761 & Strong & $<.01$ & Significant \\
Approach & .832 & Very Strong & $<.01$ & Significant \\
Responsibilities & .816 & Very Strong & $<.01$ & Significant \\
Resources & & & & \\
\hline
\end{tabular}

Table 12 reveals that all indicators of security policies/procedures, risk management practices are significantly related to its security measures. The first four indicators show strong Security Policies/Procedures Miscellaneous Rules and Regulations $(\mathrm{r}=.720, \mathrm{p}=<.01)$, Norms and Decorum $(\mathrm{r}=.702, \mathrm{p}=<.01)$, Disciplinary Measures $(\mathrm{r}=.724, \mathrm{p}=$ $<.01)$ Security Risk Management Practices Approach $(\mathrm{r}=.761, \mathrm{p}=<.01)$. The last two indicators shows very strong relationship as follows: Security Risk Management Practices Responsibilities $(\mathrm{r}=.832, \mathrm{p}=$
$<.01)$, and Resources $(r=.810, \mathrm{p}=<.01)$. Significance is clearly manifested by $\mathrm{p}$ values that are all $<.01$ significance level.

The six indicators of security policies and procedures and security risk management practices responsibilities and resources got very strong interpretation/remarks, which means that respondents perceived it as the most highly rated indicator as far as efficiency is concerned.

Table 13. Significant Relation between the Implementation of Security Policies/Procedures, Risk Management Practices and Security Measures in Terms of Effectiveness

\begin{tabular}{|l|c|c|c|c|}
\hline \multicolumn{1}{|c|}{ Indicator } & $\mathbf{r}$ & Interpretation & $\boldsymbol{p}$ & Analysis \\
\hline $\begin{array}{l}\text { Security Policies and Procedures } \\
\text { Miscellaneous Rules and Regulations }\end{array}$ & & & & \\
$\begin{array}{l}\text { Norms and Decorum } \\
\text { Disciplinary Measures }\end{array}$ & .729 & Strong & $<.01$ & Significant \\
& .715 & Strong & $<.01$ & Significant \\
& .731 & Strong & $<.01$ & Significant \\
\hline Security Risk Management Practices & & & & \\
Approach & & & & \\
Responsibilities & .771 & Strong & $<.01$ & Significant \\
$\quad$ Resources & .822 & Very Strong & $<.01$ & Significant \\
& .819 & Very Strong & $<.01$ & Significant \\
\hline
\end{tabular}

Table 13 reveals all indicators of security policies/procedures, risk management practices are significantly related to its security measures. The first four indicators show strong Security Policies/Procedures Miscellaneous Rules and Regulations $(\mathrm{r}=.729, \mathrm{p}=<.01)$, Norms and Decorum $(\mathrm{r}=.715, \mathrm{p}=<.01)$, Disciplinary Measures $(\mathrm{r}=.731, \mathrm{p}=$ $<.01)$ Security Risk Management Practices Approach $(\mathrm{r}=.771, \mathrm{p}=<.01)$. The last two indicators shows very strong relationship as follows: Security Risk Management Practices Responsibilities $(\mathrm{r}=.822, \mathrm{p}=$ $<.01$ ), and Resources $(\mathrm{r}=.819, \mathrm{p}=<.01)$. Significance is clearly manifested by $\mathrm{p}$ values that are all $<.01$ significance level.

Meanwhile, of the six indicators of security policies and procedures and security risk management practices responsibilities and resources got very strong interpretation/remarks, which means that respondents 
perceived it as the most highly rated indicator as far as effectiveness is concern.

\section{CONCLUSIONS AND RECOMMENDATIONS}

Based on the findings of the study, the following conclusions were drawn.

The null hypothesis indicating that there are no significant differences on the ratings given by the three (3) groups of respondents regarding the status of LSPU as to Policies and Procedures, Practices for Security Risk Management, and Security Measures is hereby rejected.

The null hypothesis indicating that there is no significant relationship between the LSPU Policies and Procedures, LSPU Practices for Security Risk Management, and LSPU Security Measures is hereby rejected.

The University's Officials and Administrators may allocate time and effort to explain thoroughly to its stakeholders the Laguna State Polytechnic University's Security Policies and Procedures, Security Risk Management, and Security Measures to be able to provide a safe learning and working environment to everyone inside and outside the University.

\section{LITERATURE CITED}

1. Alba, D. J., and Gable, R. K., (2011). Crisis Preparedness: Do School Administrators and First Responders Feel Ready to Act? K-12 Education. 5. https://scholarsarchive.jwu.edu/k12_ed/5.

2. Aviani, R., (2006). From Bedlam to Decorum: Improving Lunchtime. Behavior. Education Canada, v46 n2 p19-21 Spr 2006. ISSN-0013-1253.

3. Badu, A. N. Y., (2012). An Assessment on the Effectiveness of Credit Risk Management Tools Utilized by Financial Institutions in Ghana. http://hdl.handle.net/20.500.11988/93

4. Benson, J., (2019). When Rules Get in the Way. Educational Leadership, v76 n8 p34-39 May 2019. ISSN-0013-1784.

5. Black, J., and Baldwin R., (2010). Really Responsive Risk-Based Regulation. Volume 32, Issue 2. Pages 181-213. https://doi.org/10.1111/j.1467-9930.2010.00318.x.

6. Boehringer, K., Blyth, S., and Scott, F., (2012). Notes on the Emerging Accreditation Regimes in Australia and New Zealand. Higher Learning Research Communications, v2 n3 p25-29 Sep 2012. EISSN-2157-6254.

7. Booth, A., O' Farelly C., Hennessy, E., Doyle, O., (2019). Be Good, Know the Rules': Children's Perspectives on Starting School and SelfRegulation. Vol 26, Issue 4, 2019. https://doi.org/10.1177/0907568219840397.

8. Brady, K. P., Balmer, S., and Phenix, D., (2007). School-Police Partnership Effectiveness in Urban
Schools: An Analysis of New York City's Impact Schools Initiative. Vol 39, Issue 4, 2007. https://doi.org/10.1177/0013124507302396.

9. Cameron, C., and Klopper, C., (2015). University Lawyers: A Study of Legal Risk, Risk Management and Role in Work Integrated Learning Programmes. Journal of Higher Education Policy and Management, v37 n3 p344-360 2015. ISSN1360-080X.

10. Clark, S. B., DeCato, K. D., George, D., Henderson, D., Henry, A. A., Jr.; Hoch, C., (2016). Enterprise Risk Management in the Great City Schools, Spring 2016. Council of the Great City Schools.

11. Díaz-Vicario, A., Gairín Sallán, J. (2017). A Comprehensive Approach to Managing School Safety: Case Studies in Catalonia, Spain, Educational Research, v59 n1 p89-106.

12. De Guzman, E., (2009). Managing Campus Security: Everybody's Concern.

13. De Guzman, E., (2013). The Challenges of School Safety and Security.

14. Dickerson, J., (2016). How Universities Can Map Their Way to Smarter Risk and Cost Control. New England Journal of Higher Education, May 2016. ISSN-1938-5978.

15. Eisenberg, M. E., Toumbourou, J. W., Catalano, R. F., Hemphill S. A., (2014). Social Norms in the Development of Adolescent Substance Use: A Longitudinal Analysis of the International Youth Development Study. J Youth Adolescence 43, 14861497 (2014). https://doi.org/10.1007/s10964-0140111-1.

16. Ezigbo, C., (2013). Management of Risks and Implication on the Nigerian Manufacturing Sector. European Journal of Business and Management www.iiste.org ISSN 2222-1905 (Paper) ISSN 22222839 (Online) Vol.5, No.12, 2013

17. Galván, A., Spatzier, A., Juvonen, J., (2011). Perceived Norms and Social Values to Capture School Culture in Elementary and Middle School. Journal of Applied Developmental Psychology. Volume 32, Issue 6, NovemberDecember 2011, Pages 346-353. https://doi.org/10.1016/j.appdev.2011.08.005.

18. Glariana, C. E., Solar, N. J. B., (2015). Status of School Safety and Security among Elementary Schools in the Fifth Class Municipality. Asia Pacific Journal of Multidisciplinary Research Vol. 3 No.5,10-18 December 2015 Part I P-ISSN 23507756 E-ISSN 2350-8442 www.apjmr.com

19. Graham, J., Shirm, S., Liggin, R., Aitken M. E., and Dick, R., (2006). Mass-Casualty Events at Schools: A National Preparedness Survey. Pediatrics January. 2006, 117 (1) e8-e15; DOI: https://doi.org/10.1542/peds.2005-0927.

20. Grayson, J. L., (2012). The 5 Pillars of Great Campus Security.

21. Harrington, S. E., Niehaus, G., and Risko, K. J., (2005). Enterprise Risk Management: The Case of 
United Grain Growers. Journal of Applied Corporate Finance. Volume 14, Issue 4. Pages 71 81. https://doi.org/10.1111/j.17456622.2002.tb00450.x

22. Javed, M. L., and Niazi, H. K., (2015). Crisis Preparedness and Response for Schools: An Analytical Study of Punjab, Pakistan. Journal of Education and Practice. ISSN 2222-1735 (Paper) ISSN 2222-288X (Online). Vol.6, No.22, 2015.

23. Jonson, C. L, (2017). Preventing School Shootings: The Effectiveness of Safety Measures. Pages 956973 | Published online: 24 Oct 2017. https://doi.org/10.1080/15564886.2017.1307293.

24. Johnson, I. M., (1999). School Violence: The Effectiveness of a School Resource Officer Program in a Southern City. Journal of Criminal Justice. Volume 27, Issue 2, March-April 1999, Pages 173192. https://doi.org/10.1016/S0047-2352(98)00049X 